\title{
Metronidazole Inhibition of Hydrogen Production in vivo in Drug-sensitive and Resistant Strains of Trichomonas vaginalis
}

\author{
By DAVID LLOYD*† AND BODIL KRISTENSEN \\ Biochemistry Institute, University of Odense, DK 5230 Odense M, Denmark
}

(Received 15 October 1984; revised 30 November 1984)

$\mathrm{H}_{2}$ production by the human protozoan parasite Trichomonas vaginalis was monitored continuously under a mobile gas phase using a membrane-inlet mass spectrometer. Simultaneous and continuous measurement of dissolved $\mathrm{H}_{2}, \mathrm{O}_{2}$ and $\mathrm{CO}_{2}$ indicated that $\mathrm{H}_{2}$ evolution was inhibited at levels of $\mathrm{O}_{2}(<0.25 \mu \mathrm{M})$ undetectable by the technique, whereas $\mathrm{CO}_{2}$ production was stimulated. Respiration was not stimulated by admitting $\mathrm{H}_{2}$ to the gas phase. Metronidazole inhibited both $\mathrm{H}_{2}$ and $\mathrm{CO}_{2}$ production. Values of $K_{1}$ for inhibition of $\mathrm{H}_{2}$ formation in strain ATCC 30001 (metronidazole sensitive) of $0.16 \mathrm{~mm}$ and in strain 85 (metronizadole resistant) of $1.0 \mathrm{mM}$ were obtained. These data suggest that metronidazole not only competes with protons as electron acceptor but that the drug itself or a product of reduction actively inhibits some hydrogenosomal enzyme or electron carrier involved in $\mathrm{H}_{2}$ production. Under these conditions metronidazole inhibition leads to irreversible loss of cell motility,

\section{INTRODUCTION}

The antimicrobial action of metronidazole and other low-redox-potential nitroimidazoles on a variety of prokaryotic and eukaryotic anaerobes has made it an important agent in the control of infection by these organisms (Breccia et al., 1982). It has been established that the drug is reduced by ferredoxin-linked metabolic processes, and drug reduction both facilitates uptake (a passive diffusion-based process) and generates toxic derivatives which may be responsible for killing of sensitive organisms (Müller, 1983). The exact mechanism of killing is not known, but $\mathrm{O}_{2}$ plays a key role in the survival of metronidazole-resistant strains at high drug concentrations (Meingassner et al., 1978). Oxidation of nitro radical-anions by $\mathrm{O}_{2}$ (Wardman \& Clarke, 1976) has been demonstrated in vitro and in intact Trichomonas vaginalis, but is less easily accomplished in metronidazole-sensitive than in resistant strains (Lloyd \& Pedersen, 1985).

In the work described in this paper we used continuous mass spectrometric monitoring to demonstrate that metronidazole inhibition of $\mathrm{H}_{2}$ generation by $T$. vaginalis occurs both anaerobically and aerobically, but occurs at lower drug concentrations under either condition in the sensitive strain ATCC 30001 than in the resistant strain 85. Metronidazole appears to damage the $\mathrm{H}_{2}$-producing system in non-growing cells as no recovery was observed.

\section{METHODS}

Growth and hartesting of the organisms. Trichomonas vaginalis strain ATCC 30001 and strain 85, originally isolated by Dr J. Lossick (Center for Disease Control, $181 \mathrm{~S}$. Washington Boulevard, Columbus, Ǫh., USA), were grown axenically at $37^{\circ} \mathrm{C}$ for $24 \mathrm{~h}$ in tryptone/yeast extract/maltose medium, adjusted to $\mathrm{pH} 6.4$ before autoclaving and supplemented with $10 \%(\mathrm{v} / \mathrm{v})$ heat-inactivated horse serum (Diamond, 1957; Müller et al., 1980). Organisms were counted in a Fuchs-Rosenthal haemocytometer slide (Baird \& Tatlock, Chadwell Heath, Romford, Essex, UK) after fixation with $4 \%(\mathrm{v} / \mathrm{v})$ formalin. Organisms were harvested in the late exponential phase of growth (at cell densities of 2 to $3 \times 10^{6}$ organisms $\mathrm{ml}^{-1}$ ) by centrifugation at $1000 \mathrm{~g}$ for $3 \mathrm{~min}$ at room

$\dagger$ Permanent address (for correspondence): Department of Microbiology, University College, Newport Road, Cardiff CF2 ITA, Wales, UK. 
temperature in a bench centrifuge, and washed twice and resuspended in 100 mM-potassium phosphate buffer at $\mathrm{pH}$ 6.5. Maintained at high cell densities $\left(5 \times 10^{7}\right.$ organisms $\left.\mathrm{ml}^{-1}\right)$ under an atmosphere of air at room temperature or at $30^{\circ} \mathrm{C}$ no loss of motility was observed over periods of $4 \mathrm{~h}$.

Measurements of gas exchange. A quadrupole mass spectrometer fitted with a membrane-covered inlet (Lundsgaard et al., 1976; Lloyd \& Scott, 1983) was used to simultaneously and continually measure concentrations of $\mathrm{O}_{2}, \mathrm{H}_{2}$ and $\mathrm{CO}_{2}$ in an open reaction system (Degn et al., 1980). The instrument used was an SX200 (VG Gas Analysis, Middlewich, Cheshire, UK) fitted with a turbo pump (A. Pfeiffer Vacuum Technic, D-6334 Asslar, FRG), and a DPP 16 digital peak programmer.

The cell suspension $(5 \mathrm{ml})$ was maintained at $30^{\circ} \mathrm{C}$ in a cylindrical stainless-steel vessel of $7 \mathrm{ml}$ total volume. Stirring was at 700 r.p.m. by a cross-shaped stirrer; the half time for equilibration with $\mathrm{O}_{2}$ in the absence of cells was $4 \mathrm{~min}$ and was limited by the stirring rate. The concentration of $\mathrm{O}_{2}$ in air-saturated buffer at $30^{\circ} \mathrm{C}$ is $235 \mu \mathrm{M}$; the corresponding value at $\mathrm{pH} 6.5$ for $\mathrm{CO}_{2}$ is $13 \mu \mathrm{M}$, and $\mathrm{H}_{2}$-saturated buffer contains $766 \mu \mathrm{M}$ (Wilhelm et al., 1977). Concentration of dissolved $\mathrm{O}_{2}$ (Figure ordinates) under a constant partial pressure of $\mathrm{O}_{2}$ in the gas phase is linearly and inversely related to the steady-state respiration rate, whereas concentrations of $\mathrm{H}_{2}$ and $\mathrm{CO}_{2}$ are directly related to production rates. Gases were detected as the molecular ions (mass/charge ratios, designated $m / z$ values of 2, 32 and 44 for $\mathrm{H}_{2}, \mathrm{O}_{2}$ and $\mathrm{CO}_{2}$ respectively in Figs 1-3).

\section{RESULTS AND DISCUSSION}

Fig. 1 shows $\mathrm{H}_{2}$ generation by a non-proliferating suspension of $T$. vaginalis strain 30001 and the effects of changing the composition of the mobile gas phase. Until $\mathrm{O}_{2}$ dissolved in the suspension was consumed by the respiration of the organisms, $\mathrm{H}_{2}$ remained at an undetectable level. Attainment of anaerobiosis under $\mathrm{N}_{2}$ permitted $\mathrm{H}_{2}$ formation, and a steady-state level of dissolved $\mathrm{H}_{2}(9 \mu \mathrm{M})$ was achieved after about $6 \mathrm{~min}$. Low partial pressures of $\mathrm{O}_{2}(0.2-0.4 \mathrm{kPa})$ in the gas phase resulted in levels of dissolved $\mathrm{O}_{2}$ below the limit of sensitivity of the mass spectrometer $(<0.25 \mu \mathrm{M})$ but gave marked $(>60 \%)$ inhibition of $\mathrm{H}_{2}$ production. Poising dissolved $\mathrm{O}_{2}$ at $1 \mu \mathrm{M}$ gave a steady-state level of $0.5 \mu \mathrm{M}-\mathrm{H}_{2}$ (i.e. $94.5 \%$ inhibition of the anaerobic rate). Addition of $\mathrm{H}_{2}$ (up to $2.6 \mathrm{kPa}$ ) to the gas phase under these conditions gave no measurable alteration in dissolved $\mathrm{O}_{2}$ levels. This observation suggests that it is not possible to stimulate respiration with reducing equivalents derived from $\mathrm{H}_{2}$ (i.e. that no uptake hydrogenase activity is present).

Fig. 2 shows simultaneous monitoring of $\mathrm{O}_{2}, \mathrm{H}_{2}$ and $\mathrm{CO}_{2}$ dissolved in a suspension of $T$. vaginalis strain 30001 . Addition of glucose $(20 \mathrm{mM})$ stimulated $\mathrm{H}_{2}$ and $\mathrm{CO}_{2}$ evolution under anaerobiosis (Fig. 2a); switching to $0.45 \mathrm{kPa} \mathrm{O}$ completely inhibited $\mathrm{H}_{2}$ evolution, but stimulated $\mathrm{CO}_{2}$ production. Since both gases are produced from pyruvate in the hydrogenosomal compartment (Lindmark \& Müller, 1973), this experimental observation strongly suggests that the rate of pyruvate decarboxylation is limited anaerobically by the rate of electron flux through hydrogenase. Although the latter is drastically decreased or completely arrested even at low partial pressures of $\mathrm{O}_{2}$, the alternative pathway using $\mathrm{O}_{2}$ as terminal electron acceptor facilitates a more rapid decarboxylation of pyruvate. Switching back to anaerobic conditions shows that these changes are completely reversible, and indicates the operation of a reversible control mechanism rather than an $\mathrm{O}_{2}$-dependent inactivation of an electron transport component. Addition of metronidazole $(100 \mu \mathrm{M})$ gave partial inhibition of both $\mathrm{H}_{2}$ and $\mathrm{CO}_{2}$ production anaerobically $(27 \%$ and $14 \%$ respectively; Fig. $2 \mathrm{~b}$ ), and in the presence of the drug the aerobic stimulation of $\mathrm{CO}_{2}$ production was no longer observable, although $\mathrm{H}_{2}$ generation was further inhibited by $\mathrm{O}_{2}$. Restoration of anaerobiosis after a second addition of glucose $(20 \mu \mathrm{M})$ gave only partial $(60 \%)$ recovery of $\mathrm{H}_{2}$ production.

Metronidazole inhibition of $\mathrm{H}_{2}$ evolution was compared under anaerobic and aerobic conditions in non-proliferating suspensions of drug-sensitive strain 30001 and in the resistant strain 85. A typical trace is shown in Fig. 3 (strain 30001). Metronidazole additions inhibited hydrogen formation even in the presence of $\mathrm{O}_{2}$. The aerobic inhibitor titrations were performed at levels of dissolved $\mathrm{O}_{2}$ undetectable by the mass spectrometer $(<0.25 \mu \mathrm{M})$, but sufficient to give some inhibition (about $10 \%$ ) of $\mathrm{H}_{2}$ formation. Fig. 4 presents the metronidazole concentration dependence of inhibition. The presence of $\mathrm{O}_{2}$ made little difference to the extent of inhibition observed in either strain, but there was a marked difference in sensitivity between 


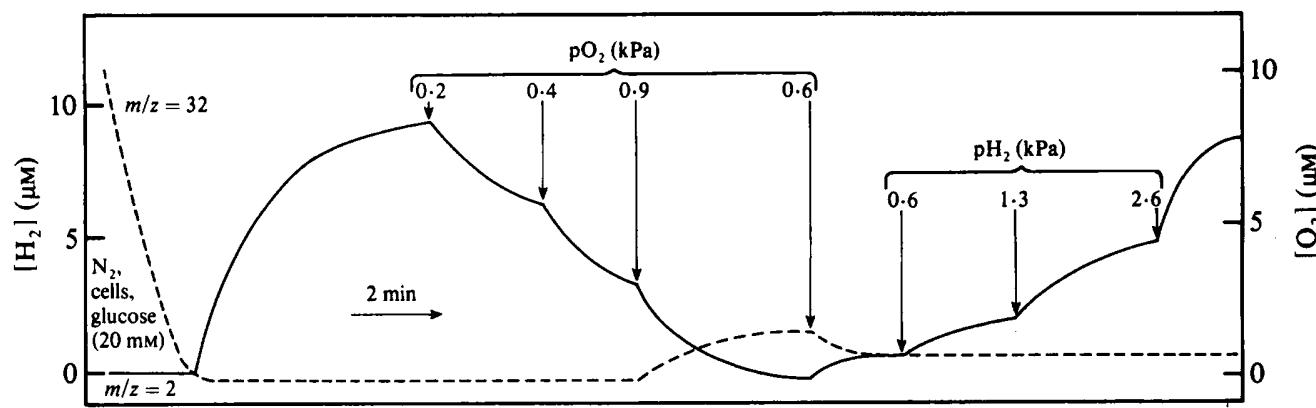

Fig. 1. Effects of $\mathrm{O}_{2}$ on $\mathrm{H}_{2}$ production and of $\mathrm{H}_{2}$ on respiration in a washed cell suspension of $T$. vaginalis strain $3000 \mathrm{I}$ in an open system, measured by mass spectrometry. The gas phase initially was pure $\mathrm{N}_{2} ; \mathrm{O}_{2}$ and $\mathrm{H}_{2}$ were added as indicated into the gas stream. ---, Dissolved $\mathrm{O}_{2}$ concentration $(\mathrm{m} / z$ $=32) ;-$, dissolved $\mathrm{H}_{2}$ concentration $(m / z=2)$. Cell density was $2 \times 10^{6}$ organisms $\mathrm{ml}^{-1}$.

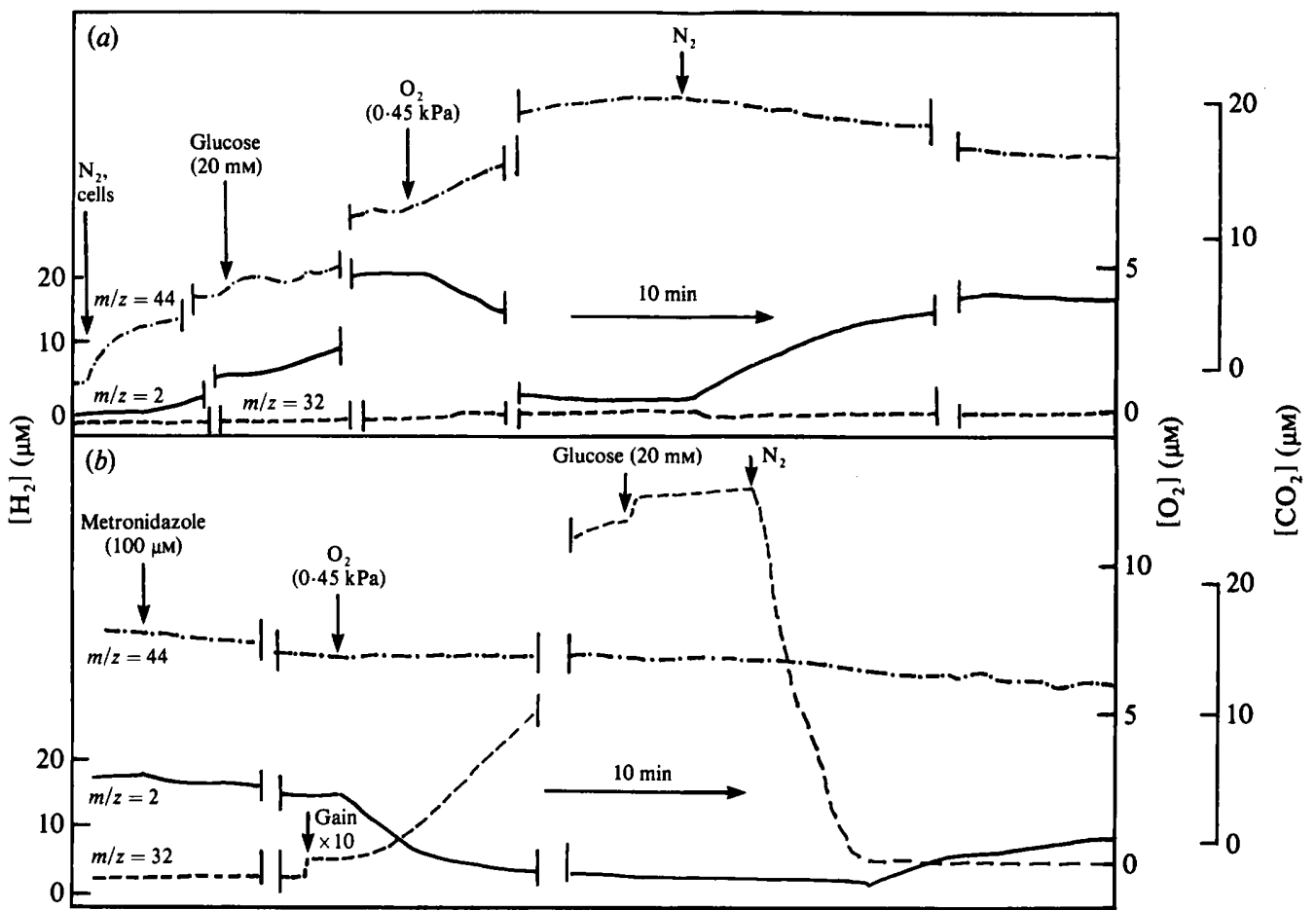

Fig. 2. Effects of $\mathrm{O}_{2}$ and metronidazole on $\mathrm{H}_{2}$ and $\mathrm{CO}_{2}$ production in a washed cell suspension of $T$. vaginalis strain 30001 in an open system. Trace $(b)$ is a continuation of trace $(a)$. Time lapses (indicated) less than $15 \mathrm{~min} . \mathrm{O}_{2}$ was added as indicated into the gas stream. ---, Dissolved $\mathrm{O}_{2}$ concentration $(\mathrm{m} / z$ $=32) ;-$, dissolved $\mathrm{H}_{2}$ concentration $(m / z=2) ;-\cdot-\cdot-$, dissolved $\mathrm{CO}_{2}$ concentration $(m / z=44)$. Cell density was $4 \times 10^{6}$ organisms $\mathrm{ml}^{-1}$.

the strains. Secondary (Dixon) plots give $K_{\mathrm{i}}$ values of $0.16 \mathrm{mM}$ and $1.0 \mathrm{mM}$ respectively for strains 30001 and 85 . Anaerobic incubation of non-proliferating cell suspensions of both strains with metronidazole present at the $K_{\mathrm{i}}$ values in the presence of $20 \mathrm{~mm}$-glucose for $2 \mathrm{~h}$ gave complete loss of motility.

These results, and the observation that no recovery from metronidazole inhibition occurred over a period of hours in the non-proliferating cell suspension, indicate that the assumed competition for electrons between metronidazole, hydrogenase and $\mathrm{O}_{2}$ in the hydrogenosome of 


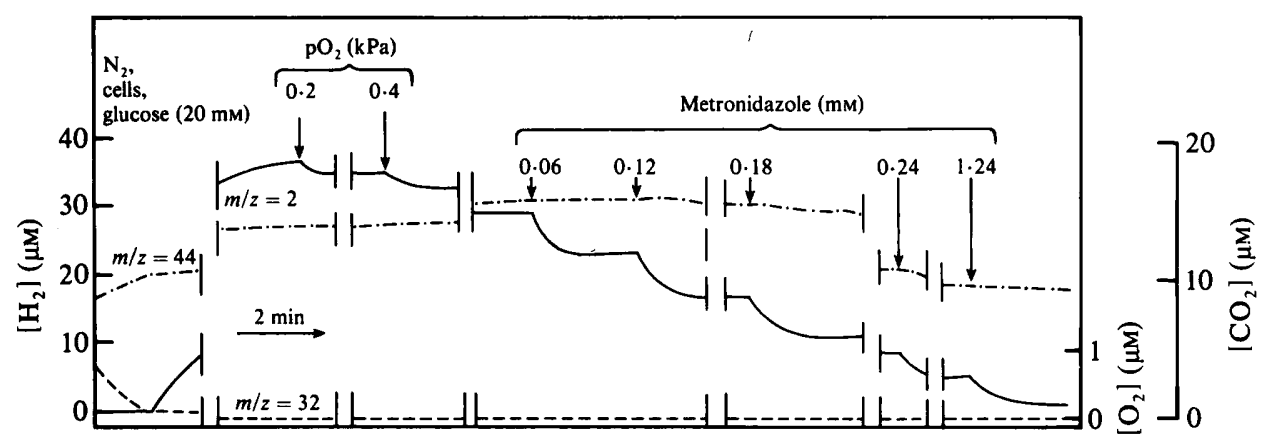

Fig. 3. Effects of $\mathrm{O}_{2}$ and metronidazole on $\mathrm{H}_{2}$ and $\mathrm{CO}_{2}$ production in a washed cell suspension of $T$.

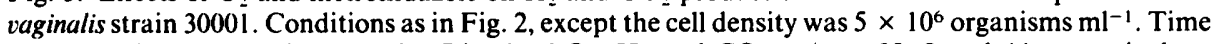
lapses (indicated) less than $15 \mathrm{~min}$. Dissolved $\mathrm{O}_{2}, \mathrm{H}_{2}$ and $\mathrm{CO}_{2}, m / z=32,2$ and 44 respectively.

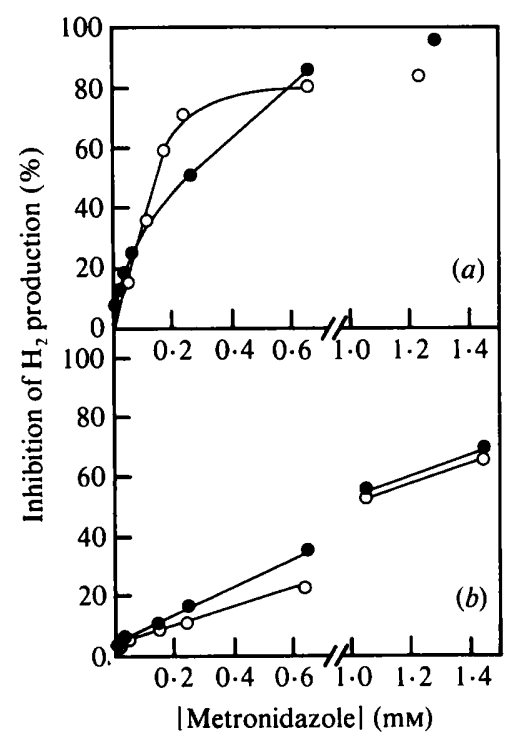

Fig. 4. Inhibition of $\mathrm{H}_{2}$ generation by metronidazole in (a) drug-sensitive (strain 30001 ) and (b) drugresistant (strain 85) T. vaginalis. Anaerobic titrations were performed under a gas phase of $\mathrm{N}_{2}(\mathrm{O})$; aerobic conditions were established under $0.4 \mathrm{kPaO}_{2}(\mathrm{O})$. Similar results were obtained in two separate experiments.

T. vaginalis (O'Brian \& Morris, 1972; Coombs, 1976; Edwards et al., 1973) is not a complete explanation for the effect of the drug on $\mathrm{H}_{2}$ production. As discussed above, stimulation of $\mathrm{CO}_{2}$ output during the transition to aerobiosis indicates that anaerobic electron flux is limited by hydrogenase (or some electron carrier mediating electron flow from pyruvate to hydrogenase). Competition for electrons by metronidazole would not alter the rate of $\mathrm{H}_{2}$ formation, as the capacity of this electron transport pathway would still be saturated in the presence of the drug, i.e. the electron supply rate greatly exceeds hydrogenase activity. Even if hydrogenase was not rate limiting, addition of small concentrations of the drug would give only transient depression of $\mathrm{H}_{2}$ formation for stoichiometric reduction. The attainment of successively lower steady-state levels of $\mathrm{H}_{2}$ production (under both anaerobic and aerobic conditions) observed here suggests direct interaction of the drug or one of its reduced products (the nitro radical-anion, nitroso or hydroxylamine derivatives) with some component of the electron transport chain (Ohnishi et al., 1980) between pyruvate and hydrogenase. That inhibition still occurs when $\mathrm{O}_{2}$ is present does not rule out the possibility that the nitro radical-anion is involved. Although this species is auto- 
oxidizable (Wardman \& Clarke, 1976), at the low level of dissolved $\mathrm{O}_{2}(<0.25 \mu \mathrm{M})$ used in these experiments metronidazole radicals persist (Lloyd \& Pedersen, 1985). Current explanations for metronidazole killing of trichomonads (Edwards et al., 1973; Brecchia et al., 1982) are not adequate to account for the effects described here with non-proliferating organisms.

D. L. wishes to thank Dr H. Degn and Dr R. P. Cox for their interest and encouragement and Dr M. Müller, Dr N. Yarlett and Mrs N. C. Yarlett for providing organisms.

\section{REFERENCES}

Breccia, A., Cavalleri, B. \& Adams, G. E. (editors) (1982). Nitroimidazoles: Chemistry, Pharmacology and Clinical Applications. New York: Plenum.

Coombs, G. H. (1976). Studies on the activity of nitroimidazoles. In Biochemistry of Parasites and Host-Parasite Relationships, pp. 545-552. Edited by H. van den Bossche. Amsterdam: North Holland.

Degn, H., Lundsgaard, J. S., Petersen, L. C. \& OrMICKI, A. (1980). Polarographic measurement of steady state kinetics of oxygen uptake by biochemical samples. Methods of Biochemical Analysis 26, 4777.

Diamond, L. (1957). The establishment of various trichomonads of animals and man in axenic cultures. Journal of Parasitology 43, 488-490.

Edwards, D. I., Dye, M. \& Carne, H. (1973). The selective toxicity of antimicrobial nitroheterocycle drugs. Journal of General Microbiology 76, 135145.

LindMaRK, D. G. \& Müller, M. (1973). Hydrogenosome, a cytoplasmic organelle of the anaerobic flagellate Tritrichomonas foetus, and its role in pyruvate metabolism. Journal of Biological Chemistry 248, 7724-7728.

Lloyd, D. \& Pedersen, J. Z. (1985). Metronidazole radical anion generation in vivo in Trichomonas vaginalis: $\mathrm{O}_{2}$ quenching is enhanced in a drugresistant strain. Journal of General Microbiology 131, 87-92.

LLOYD, D. \& SCOTT, R. I. (1983). Direct measurement of dissolved gases in microbiological systems using membrane inlet mass spectrometry. Journal of Microbiological Methods 1, 313-328.

Lundsgaard, J. S., Petersen, L. C. \& Degn, H.
(1976). Mass spectrometric determination of oxygen kinetics in biochemical systems. In Measurements of Oxygen, pp. 168-183. Edited by H. Degn, I. Balslev \& R. Brook. Amsterdam: Elsevier.

MeINGassner, J. G., Meith, H., CZoK, R., Lindmark, D. G. \& MüLlER, M. (1978). Assay conditions and the demonstration of nitroimidazole resistance in Tritrichomonas foetus. Antimicrobial Agents and Chemotherapy 13, 1-13.

MüLLER, M. (1983). Mode of action of metronidazole on anaerobic bacteria and protozoa. Surgery 93,165 171.

Müller, M., Meingassner, J. G., Miller, W. A. \& LEDGER, W. J. (1980). Three metronidazole-resistant strains of Trichomonas vaginalis from the United States. American Journal of Obstetrics and Gynecology 138, 808-812.

O'Brian, R. W. \& Morris, J. G. (1972). Effect of metronidazole on hydrogen production by Clostridium acetobutylicum. Archives of Microbiology 84, 225-233.

OHNISHI, T., LLOYD, D., LiNDMARK, D. G. \& Mü LLER, M. (1980). Respiration of Trichomonas foetus: components detected in hydrogenosomes and in intact cells by electron paramagnetic resonance spectrometry. Molecular and Biochemical Parasitology 2, 39-50.

Wardman, P. \& Clarke, E. D. (1976). Oxygen inhibition of nitroreductase: electron transfer from nitro radical-anions to oxygen. Biochemical and Biophysical Research Communications 69, 942-949.

Wilhelm, E., Battino, R. \& Wilcock, R. J. (1977). Low pressure solubility of gases in liquid water. Chemical Reviews 77, 226-250. 